\title{
Pengaruh Pembelajaran Online terhadap Tingkat Motivasi Belajar Mahasiswa/Mahasiswi Feb Akuntansi UKSW di Masa Pandemi Covid 19
}

\author{
Katharina Ardian Wolo ${ }^{1 *}$, Paskah Ika Nugroho ${ }^{2}$ \\ ${ }^{123}$ Fakultas Ekonomika dan Bisnis, Universitas Kristen Satya Wacana \\ *232016262@student.uksw.edu ${ }^{I^{*}}$
}

\section{Abstrak}

Dunia saat ini sedang dihadapi dengan merebaknya wabah virus COVID 19. Hal tersebut jelas berpengaruh signifikan terhadap berbagai bidang terutama pendidikan. Oleh karenanya dibutuhkan motivasi belajar sebagai salah satu bentuk sikap kritis dalam mengimbangi situasi pendidikan yang kini mengkhawatirkan. Motivasi belajar merupakan faktor esensial dalam bidang pendidikan. Penelitian ini dilakukan dengan tujuan untuk melihat pengaruh pembelajaran online terhadap motivasi belajar mahasiswa/ mahasiswi FEB Akuntansi UKSW. Penelitian ini menggunakan pendekatan kuantitatif, dengan membagikan kuesioner kepada mahasiswa/mahasiswi FEB akuntansi. Sampel yang diambil dari penelitian ini yaitu mahasiswa/mahasiswi angkatan 2017, 2018, dan 2019 dengan jumlah sebanyak 63 responden. Teknik analisis yang digunakan dalam penelitian ini yaitu teknik analisis regresi linear sederhana. Penelitian ini juga dilakukan dengan uji validitas dan reliabilitas, uji normalitas data, uji linearitas, uji hipotesis dan koefisien determinan. Hasil penelitian menunjukkan nilai signifikansi dari uji hipotesis sebesar 0,000 lebih kecil dari 0,005. Hal ini berarti pembelajaran online berpengaruh positif terhadap motivasi belajar mahasiswa / mahasiswi FEB akuntansi UKSW. Selain itu, nilai koefisien determinan atau $r$ square 0,248 yang berarti pembelajaran online berkontribusi terhadap motivasi belajar sebesar 0,248 atau $24,8 \%$ dan sisanya dipengaruhi oleh variabel lain.

Kata Kunci: Pendidikan, COVID 19, Pembelajaran online, Motivasi belajar

\section{Abstract}

The world nowadays is currently being faced with the outbreak of the COVID 19 virus. This clearly has a significant effect on various fields, especially education. Therefore, it takes motivation to learn as a form of critical attitude in balancing the currently worrisome educational situation. Motivation to learn is an essential factor in the field of education. This research was purposed to see the effect of online learning on the learning motivation of SWCU Accounting FEB students. This study uses a quantitative approach, by distributing questionnaires to accounting FEB students. The samples taken from this study were students of class 2017, 2018, and 2019 with a total of 63 respondents. The analysis technique used in this study is a simple linear regression analysis technique. This research was also conducted by testing the validity and reliability, data normality test, linearity test, hypothesis testing and determinant coefficient. The results showed that the significance value of the hypothesis testing was 0.000 less than 0.005. It means that online learning has a positive effect on the learning motivation of SWCU accounting FEB students. In addition, the value of the determinant coefficient or $r$ square is 0.248 , which means that online learning contributes to learning motivation by 0.248 or $24.8 \%$ and the rest is influenced by other variables.

Keywords: Education, COVID 19, Online learning, Motivation to learn

\section{Pendahuluan}

Pendidikan adalah suatu proses pembelajaran kepada peserta didik agar mampu mengembangkan kemampuan dan keterampilan yang dimilikinya. Adanya penerapan pendidikanbaik di sekolah maupun di luar sekolah dapat menghasilkan perubahan dalam pengetahuan dan karakter peserta didik. Perubahan tersebutdapat membantu Pemerintah dalam menciptakan daya saing yaitu dengan adanya SDM yang bermutu. Hal ini tentunya membuat pendidikan menjadi sangat penting, terutama dalam kondisi yang terjadi saat ini

\footnotetext{
History:

Received: 05 April 2021

Revised: 26 Juni 2021

Accepted: 28 Juni 2021

Published: 30 Juni 2021
}

Publisher: Undiksha Press

Licensed: This work is licensed under

a Creative Commons Attribution 3.0 License

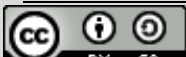


yaitu munculnya wabahCOVID19. Virus ini sudah menyebar ke berbagai negara di duniadan menimbulkan dampak di beberapa bidang, salah satunya dalam bidang pendidikan. Hal ini menuntut pendidik maupun peserta didik agar mampu menghadapi kondisi tersebut untuk mencapai keberhasilan pendidikan.

Motivasi belajar menjadi salah satu faktor yang mendukung keberhasilan pendidikan. Sardiman (2016)menjelaskan bahwa motivasi belajar merupakan kemampuan mendorong untuk belajar dalam diri seseorang yang nantinya akanmengalami perubahan dalam dirinya. Perubahan tersebut sangat dipengaruhi oleh berbagai faktor, contohnya seperti lingkungan, budaya, dan media pembelajaran yang digunakan.Aghni (2018) menyatakan akuntansi merupakan salah satu mata kuliah yang mewajibkan mahasiswa memahami teori dan hitungan secara bersamaan. Hal ini menuntut pendidik agar mampu memilih media pembelajaran yang tepat mahasiswa.Mediapembelajaran merupakan suatu sarana komunikasi dalam menyampaikan materi pembelajaran kepadapeserta didik sehingga dapat mendorong maupun memotivasi peserta didik dalam proses pembelajaran(Daryanto, 2016). Ada berbagai macam media pembelajaran yang diterapkan dalam proses pembelajaran seperti pembelajaran tatap muka secara langsung maupun pembelajaran jarak jauh. Setiap peserta didik tentunya memiliki motivasi belajar yang berbeda, sehingga pendidik harus mampu memilih media pembelajaran yang tepat bagi peserta didik.Dimas (2020)menyatakanmaraknyaCOVID 19 membuat pendidik maupun peserta didik merasa terganggu dalam proses pembelajaran. Selain itu, Pemerintah sudah menetapkan beberapa kebijakan dalam bidang Pendidikan, salah satunyayaitu penerapan pembelajaranonlinebagi sekolah maupun universitas.

Pembelajaran onlinetentu tidak asing bagi pendidikan saat ini, karena ada beberapa sekolah maupun universitas yang sudah menggunakan media pembelajaran tersebut, akan tetapimungkin menjadi masalah bagi sekolah maupun universitas yang belum pernah menggunakan media tersebut dalam proses pembelajaran. Media pembelajaran yang digunakan mahasiswa/mahasiswi FEB Akuntansi UKSW dalam proses pembelajaran sebelum adanya COVID 19yaitu pembelajaran tatap muka secara langsung dan juga online, namun pembelajaran onlineinibelum sepenuhnya dilakukan. Hal ini membuat peneliti memilih objek penelitian pada mahasiswa/mahasiswi FEB Akuntansi UKSW. Selain itu, berdasarkan pengamatan peneliti ada beberapa mahasiswa yang mengalami kendala dalam pembelajaranonlinedi masa pandemicCOVID 19 ini. Kendala yang dialami berupa koneksi internet yang kadang-kadanglambat, dikarenakan mahasiswa berada di daerah yang berbedabeda. Hal ini bisa memicu mahasiswa menjadi kurang fokus dan malas dalam pelaksanaan pembelajaranonline tersebut, sehingga mahasiswa tidak terlalu memahami pembelajaran yang disampaikan.

Danaswari dan Gafur (2018)menyatakan hasil penelitian dengan menggunakan pendekatan kualitatif dan kuantitatif menunjukkan bahwa adanya peningkatan motivasi belajar siswa setelah menggunakan pengembangan multimedia pembelajaran berbasis web. Hal ini juga didukung dari penelitianIrmayanti dan Nugroho (2016)yang menjelaskan bahwa media berbasis web blog juga dapat meningkatkan motivasi belajar siswa. Selain itu, dalam penelitianNoor dan Aisyah (2018) dengan menggunakan angket dan sampel sebanyak 33 siswa menyatakan bahwa media pembelajaran interaktif dalam mata pelajaran akuntansi dasar dapat meningkatkan motivasi belajar siswa. Jumlah responden yang terlibat dari penelitian terdahulu sedikit, sehingga peneliti tersebut menyarankan untuk menambah responden di penelitian berikutnya. Hal ini memicu peneliti untuk melakukan penelitian dengan jumlah responden yang lebih banyak dari penelitian terdahulu. Selain itu, dalam penelitian ini memunculkanpertanyaan penelitian yaitu apakah mahasiswa/mahasiswi FEB Akuntansi UKSW memiliki motivasi belajar yang tinggi atau rendah dengan adanya pembelajaranonline di masa pandemicCOVID19. Tujuan dari penelitian ini yaitu untuk 
mengetahui tingkat motivasi belajar mahasiswa/mahasiswi FEB Akuntansi UKSW dalam menggunakan media pembelajaran online di masa pandemicCOVID 19. Adapun manfaat penelitian bagi pendidik maupun peserta didik akan pentingnya pembelajaran online, mampu memilih metode yang tepat dan sesuai dalam proses pembelajaran akuntansi secara online.

Motivasi Belajar Akuntansi

Sardiman (2016) menjelaskan bahwa motivasi adalah suatu dorongan dalam diri seseorang untuk melakukan, mengerjakan suatu aktivitas agar mencapai tujuan dan kebutuhan dalam dirinya. Selain itu, motivasijuga dapat dipengaruhi oleh faktor-faktor eksternal, salah satunya berupa lingkungan. Motivasi ditandai dengan kesungguhan seseorang dalam bekerja, kuat dalam menghadapi kesulitan, mandiri, cepat merasa jenuh terhadap kegiatan rutin, memiliki minat, mempertahankan pendapatnya, tidak mudah meninggalkan hal yang diyakini itu, tertarik dalam mencari dan memecahkan soal-soal (Sardiman, 2016).

Belajar merupakan suatu proses yang dilakukan seseorang untuk mencapai perubahan karakter menyeluruh dan sebagai hasil dari interaksi dengan lingkungannya (Januar, 2015). Belajar yaitu suatu kegiatanyang dilakukan seseorang baik di dalam lingkungan sekolahmaupun di luar sekolah yang ditandai dengan adanya perubahan dalam dirinya. Menurut Kusumadyahdewi (2017)akuntansi adalah suatu sistem yang meliputi input transaksi-transaksi dan diproses untuk menghasilkan informasi keuangan. Kegiatan yang termasuk dalam proses akuntansi yaitu mengidentifikasi, mencatat dan mengkomunikasikan informasi keuangan kepada pengguna informasi. Rista dan Ariyanto (2018) menyatakan bahwa seseorang dapat belajar dengan giat disebabkan adanya motivasi belajar dalam dirinya. Motivasi belajar akuntansi adalah kondisi ketika seseorang merasa tergerak untuk belajar mengenai akuntansi. Tingkat tinggi dan rendah motivasi belajar seseorang sangat dipengaruhi oleh berbagai faktor.

Pembelajaran Online

Rusman (2017)menjelaskan bahwaterdapat beberapa komponen dalam pembelajaran yang saling berhubungan diantaranya tujuan pembelajaran, sumber belajar, media pembelajaran, strategi pembelajaran, dan evaluasi pembelajaran. Pembelajaran adalah suatu proses interaksi antara pendidik, siswa dan sumber belajar(Rusman, 2017). Interaksi ini dapat terjadi secara langsung maupun tidak langsung dengan menggunakan media pembelajaran baik secara tatap muka maupun melalui internet.

Media pembelajaran merupakan suatu alat yang mendukung dalam proses pembelajaran. Adanya media pembelajaran tersebut dapat membantu pendidik maupun peserta didik dalam pencapaian tujuan pembelajaran. Pembelajaran online merupakansalah satu media pembelajaran dengan menggunakan bantuan internet dan media digital seperti zoom application, google meet, situs web, dan video. Pembelajaran online ini ditandai dengan adanya kegiatan pembelajaran yang dilakukan oleh pendidik dan peserta didik dalam waktu bersamaan.

Model penelitian ini menjelaskan tentang pengaruh pembelajaran online terhadap motivasi belajar. Pengembangan hipotesis dapat dilihat pada gambar di bawah ini. Variabel 6yang digunakan dalam penelitian ini adalah variabel independen, yaitu pengaruh pembelajaran online dan variabel dependen dalam penelitian ini adalah motivasi belajar.

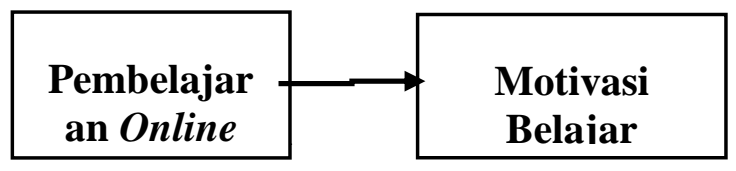




\section{Hubungan Pembelajaran Online dan Motivasi Belajar}

Media pembelajaran merupakan alat yang digunakan sebagai perantara dalam proses pembelajaran. Media pembelajaran memiliki berbagai bentuk yaitu dengan tatap muka secara langsung maupun pembelajaran menggunakan bantuan internet. Pembelajaran tatap muka merupakan media utama dalam proses pembelajaranyang dilakukan oleh pendidik dengan memberi penjelasan kepada peserta didik dalam suatu ruangan secara langsung. Proses pembelajaran ini bisa saja menimbulkan rasa bosan dan penurunan tingkat motivasi belajar siswa. Hal ini dikarenakan proses pembelajaran yang dilakukan tidak bervariasi. Aghni (2018)menjelaskan bahwa setiap siswa memiliki gaya belajar yang berbeda-beda. Selain itu, siswa juga membutuhkan wadah dalam mengembangkan potensi yang dimiliki sehingga proses pembelajaran tidak hanya dengan penjelasan dari pendidik. Pembelajaran online merupakan salah satu wadah bagi setiap orang dalam proses pembelajaran dengan menggunakaninternetmaupun media digital. Adanya pembelajaran onlinemembuat setiap orang dapat mengakses nya dimanapun dan dapat belajar secara mandiri. Pembelajaran onlineyang efektif menjadi penting dalam proses pembelajaran peserta didik. Hal ini dikarenakan sangat berpengaruh terhadap tingkat motivasi belajar peserta didik.

Brahma (2020) menjelaskan bahwa penggunaan zoom dalam pembelajaran onlinedimasa pandemicCOVID 19 membuat mahasiswa menjadi tertarik danpembelajaran berjalan dengan efektif.Danaswari dan Gafur (2018) mengatakan bahwa dengan adanya penggunaan multimedia berbasis web, motivasi belajar dari peserta didik menjadi meningkat. Hal ini serupa dengan penelitian Sitorus (2020) yang menyatakan media pembelajaran jarak jauh dengan menggunakan video animasi membuat motivasi belajar siswa menjadi tinggi.Berdasarkan penelitian terdahulu dan argumentasi yang dipaparkan dapat dirumuskan hipotesis sebagai berikut:

$\mathrm{H}_{1}$ : Pembelajaran online berpengaruh positif terhadap motivasi belajar mahasiswa/mahasiswi Akuntansi

\section{Metode}

Penelitian ini memiliki tujuan yaitu untuk mengetahui apakah ada pengaruh antara pembelajaran online dan motivasi belajar mahasiswa/mahasiswi FEB Akuntansi UKSW selama masa pandemiCOVID 19. Ada dua variabel yang digunakan dalam penelitian ini yaitu variabel bebas berupa pembelajaran online dan variabel terikat berupa motivasi belajar. Penelitian ini menggunakan pendekatan kuantitatif yang dilakukan dalam bentuk kuesioner yang berisi pernyataan-pernyataan dan akan dianalisis menggunakan statistik.

Wahidmurni (2017) menjelaskan bahwa penelitian kuantitatif adalah pendekatan penelitian dengan membuktikan teori melalui pengukuran variabel. Pengukuran tersebut dapat dilakukan menggunakan instrumen dan dianalisis menggunakan statistik. Peneliti dapat menggunakan pendekatan kuantitatif guna menjawab masalah penelitian yang berhubungan dengan data yakni data angka (Wahidmurni, 2017).

Populasi dalam penelitian ini yaitu mahasiswa/mahasiswi FEB Akuntansi UKSW. Penentuan populasi dalam penelitian ini didasarkan dengan alasan bahwa FEB Akuntansi UKSW merupakan salah satu program studi yang menggunakan pembelajaran online di masa pandemicCOVID 19. Selain itu, program studi ini memberikan kontribusi yang cukup besar dalam melakukan pembelajaran online. Teknik pengambilan sampel dalam penelitian ini yaitu dengan cluster random sampling. Teknik ini merupakan pengambilan sampel secara acak tanpa memperhatikan strata dan semua populasi dianggap sama.

Jenis data yang digunakan yaitu data primer dengan penyebaran kuesioner kepada mahasiswa/mahasiswi FEB Akuntansi UKSW yaitu dengan mengambil dari beberapa angkatan. Mahasiswa/mahasiswi yang termasuk dalam pengambilan sampel yaitu angkatan 
2017, angkatan 2018, dan angkatan 2019. Hal ini dikarenakan mahasiswa/mahasiswi angkatan 2017, angkatan 2018, dan angkatan 2019 lebih banyak berkontribusi dalam pelaksanaan pembelajaran online selama masa pandemicCOVID 19. Selain itu, pengambilan sampel ini ditujukan untuk mahasiswa yang mengambil maupun mengulang mata kuliah akuntansi di masa pandemic COVID 19. Skala pengukuran yang digunakan berupa skala ordinal dengan lima tingkatan yaitu sangat setuju, setuju, netral, tidak setuju, sangat tidak setuju.

Penelitian ini diawali dengan pengujian kualitas data yaitu berupa uji validitas dan reliabilitas melalui aplikasi SPSS. Teknik analisis yang digunakan dalam penelitian ini berupa teknik analisis regresi linier sederhana. Hasil dari teknik analisis ini akan digunakan untuk melihat apakah hipotesis dari peneltian ini diterima atau ditolak.

\section{Uji Validitas}

Uji validitas merupakan suatu pengujian untuk menunjukkan alat ukur yang digunakan dalam penelitian valid atau tidak valid. Ada berbagai alat ukur dalam penelitian, salah satunya yaitu kuesioner, yang didalamnya terdapat berbagai pertanyaan maupun pernyataan. Pertanyaan maupun pernyataan tersebut akan di uji kevalidannya sebelum melakukan teknik analisis lainnya. Kriteria yang digunakan untuk menentukan alat ukur tersebut valid atau tidak valid yaitu dengan melihat nilai $r$ hitung dan $r$ tabel dengan tingkat signifikansi yang digunakan 0,05. Jika $r$ hitung $>r$ tabel, maka alar ukur tersebut valid dan jika $r$ hitung $<r$ tabel, maka alat ukur tersebut tidak valid (Hulu dan Sinaga, 2019). Nilai $r$ hitung kita dapat melihatnya di aplikasi SPSS, sementara $r$ tabel terdapat pada tabel $r$. Rumus yang digunakan yaitu $\mathrm{df}=(\mathrm{N}-2)$, tingkat signifikansi uji dua arah dengan $\mathrm{N}=$ jumlah sampel.

\section{Uji Reliabilitas}

Reliabilitas yaitu tingkat konsistensi dari hasil yang dinilai atau diukur dengan alat ukur yang sama dan topik yang serupa. Uji reliabilitas dilakukan dengan tujuan untuk melihat kesesuaian jawaban responden dari pernyataan yang diberikan dalam kuesioner. Selain itu, dapat dilihat juga dari konsistensi jawaban responden dengan pernyataan yang sama meskipun dalam waktu yang berbeda. Suatu pernyataan dikatakan reliabel jika memiliki nilai cronbach's alpha $>0,06$ dan dikatakan tidak reliabel jika nilai cronbach's alpha $<0,06$ (Hulu dan Sinaga, 2019).

\section{Uji Normalitas}

Uji normalitas digunakan untuk melihat nilai residual berdistribusi normal atau tidak. Nilai residual yang berdistribusi normal akan menghasilkan model regresi yang baik yang baik. Pengujian normalitas suatu nilai residual dapat dilakukan dengan uji kolmogorovsmirnov, yang hasilnya dilihat dari nilai signifikansi. Selain itu, dapat dilakukan dengan pengujian lain seperti uji normal p plot, uji histogram. Data dikatakan berdistribusi normal jika nilai signifikansinya lebih besar dari 0,05 dan jika nilai signifikansinya lebih kecil dari 0,05 maka data tersebut tidak berdistribusi normal(Kurniawan, 2019).

\section{Uji Linearitas}

Uji linearitas dilakukan dengan tujuan untuk menguji apakah model yang dibangun atau variabel independent dan dependent memiliki hubungan yang linear. Untuk mengetahui apakah kedua variabel tersebut memiliki hubungan linear dapat dilihat dari nilai signifikansi maupun membandingkan $\mathrm{F}$ hitung dan $\mathrm{F}$ tabel. Jika nilai defiation from linearity sig $>0,05$ maka terjadi hubungan yang linear antara kedua variabel tersebut. Jika nilai defiation from linearity $<0,05$ maka tidak terjadi hubungan yang linear antara kedua variabel tersebut (Marzuki, etc : 2020). 


\section{Teknik Analisis Regresi Linear Sederhana}

Penelitian ini menggunakan teknik analisis regresi linier sederhana yaitu dengan menguji pengaruh variabel independen atau $\mathrm{X}$ terhadap variabel dependen atau Y. Teknik ini menggunakan satu variabel independen yaitu pembelajaran online dan satu variabel dependen yaitu motivasi belajar. Model persamaan linier sederhana yang digunakan yaitu:

$Y=a+b X+e$

dengan,

$\mathrm{Y}=$ variabel dependen

$\mathrm{a}=$ konstanta

$\mathrm{b}=$ koefisien variabel independen

$\mathrm{X}=$ variabel independen

$\mathrm{e}=$ error

Uji Hipotesis

Tujuan melakukan uji hipotesis yaitu untuk mengetahui apakah ada pengaruh atau tidak variabel independent terhadap dependent. Kriteria untuk melihat pengaruh variabel independen terhadap dependent yaitu dengan melihat hasil analisis regresi berupa nilai signifikansi atau membandingkan nilai $t$ hitung dengan $t$ tabel. Jika nilai signifikansi lebih kecil dari 0,05, maka ada pengaruh variabel independent terhadap variabel dependent. Jika nilai signifikansi lebih besar dari 0,05 , maka tidak ada pengaruh variabel independent terhadap variabel dependent.

Variabel independen merupakan variabel yang mempengaruhi timbulnya variabel dependen. Variabel independen dalam penelitian ini adalah pembelajaran online sedangkan variabel dependen merupakan variabel yang dipengaruhi atau yang menjadi akibat karena adanya variabel independen. Variabel dependen dalam penelitian ini adalah motivasi belajar.

Tabel 1. Definisi Operasional

\begin{tabular}{|c|c|c|c|c|}
\hline Variabel & Definisi & Indikator & Skala & Alat Ukur \\
\hline $\begin{array}{l}\text { Motivasi } \\
\text { belajar (Y) }\end{array}$ & $\begin{array}{lr}\text { kondisi } & \text { dimana } \\
\text { seseorang } & \text { merasa } \\
\text { tergerak } & \text { atau } \\
\text { terdorong } & \text { untuk } \\
\text { melakukan } & \text { kegiatan } \\
\text { belajar(Sardiman, } \\
\text { 2016). }\end{array}$ & $\begin{array}{ll}\text { 1. } & \text { Tekun menghadapi } \\
\text { tugas } \\
\text { 2. Ulet menghadapi } \\
\text { kesulitan } \\
\text { 3. Memiliki minat } \\
\text { terhadap berbagai soal } \\
\text { 4. Lebih senang b`elajar } \\
\text { mandiri } \\
\text { 5. Dapat } \\
\text { mempertahankan } \\
\text { pendapat } \\
\text { Tidak mudah } \\
\text { melepaskan hal yang } \\
\text { diyakini } \\
\text { 7. Senang mencari dan } \\
\text { memecahkan soal-soal } \\
\text { (Sardiman, 2016) }\end{array}$ & Ordinal & Kuesioner \\
\hline $\begin{array}{l}\text { Pembelajaran } \\
\text { online }(\mathrm{X})\end{array}$ & $\begin{array}{l}\text { Salah satu media } \\
\text { pembelajaran yang } \\
\text { digunakan dalam } \\
\text { proses pembelajaran } \\
\text { oleh pendidik dan } \\
\text { peserta didik di } \\
\text { tempat yang berbeda } \\
\text { dengan bantuan }\end{array}$ & $\begin{array}{l}\text { 1. Aplikasi atau sistem } \\
\text { yang digunakan } \\
\text { dalam } \\
\text { pembelajaran } \\
\text { online } \\
\text { 2. Mudah atau susah } \\
\text { dalam mengakses } \\
\text { aplikasi }\end{array}$ & Ordinal & Kuesioner \\
\hline
\end{tabular}




$\begin{array}{lll}\text { internet } & \text { (Riyana, } & \text { 3. } \\ \text { 2018). } & \text { didik dalam } \\ & \text { menggunakan } \\ & \text { media } \\ & \text { pembelajaran } \\ & \text { online }\end{array}$

\section{Hasil dan Pembahasan}

Responden yang berkontribusi dalam penelitian ini yaitu mahasiswa FEB Akuntansi UKSW angkatan 2017,2018, dan 2019. Dari beberapa angkatan tersebut, peneliti memperoleh jumlah responden sebanyak 64 orang, tetapi yang digunakan dalam penelitian ini hanya 63 responden, karena ditemukan satu responden yang tidak mengisi kuesioner secara lengkap.

Table 1. Angkatan

\begin{tabular}{lcl}
\hline Angkatan & Jumlah responden & \% \\
\hline 2017 & 12 & 19,0 \\
\hline 2018 & 21 & 33,3 \\
\hline 2019 & 30 & 47,6 \\
\hline Total & 63 & 100.0 \\
\hline
\end{tabular}

Sumber: Software SPSS

Data diatas menunjukkan persentase responden dari berbagai angkatan. Angkatan yang paling berkontribusi dalam penelitian ini yaitu angkatan 2019 berjumlah 30 orang dengan persentase sebesar 47,6 persen, angkatan 2018 berjumlah 21 orang dengan persentase sebesar 33,3 persen, angkatan 2017 berjumlah 12 orang denganpersentase sebesar 19,0 persen.

Table 2. IPK

\begin{tabular}{ccc}
\hline Jumlah responden & Nilai minimum & Nilai maksimum \\
\hline 63 & 2,90 & 3,98 \\
\hline
\end{tabular}

Sumber: Software SPSS

IPK responden yang ditunjukan dari data diatas yaitu dengan IPK terendah 2,90, IPK tertinggi 3,98. Rata-rata IPK responden yaitu berada pada angka 3,5541.

Table 3. Statistik Deskriptif Variabel

\begin{tabular}{lccccc}
\hline \multicolumn{1}{c}{ Variabel } & $\begin{array}{c}\text { Jumlah } \\
\text { Responden }\end{array}$ & $\begin{array}{c}\text { Nilai } \\
\text { minimum }\end{array}$ & $\begin{array}{c}\text { Nilai } \\
\text { maksimum }\end{array}$ & $\begin{array}{c}\text { Rata- } \\
\text { rata }\end{array}$ & $\begin{array}{c}\text { Standar } \\
\text { Deviasi }\end{array}$ \\
\hline $\begin{array}{l}\text { Pembelajaran } \\
\text { Online }\end{array}$ & 63 & 17 & 40 & 28,14 & 5,076 \\
\hline $\begin{array}{l}\text { Motivasi } \\
\text { Belajar }\end{array}$ & 63 & 33 & 56 & 42,48 & 6,138 \\
\hline
\end{tabular}

Sumber: Software SPSS

Data diatas menunjukkan jumlah responden yang sama dari setiap variabel yaitu sebanyak 63 orang. Dari banyaknya responden tersebut, ditunjukkan variabel pembelajaran online memiliki nilai minimum sebesar 17 , nilai maksimum 40 , nilai rata-rata 28,14 , dan nilai standar deviasi 5,076. Nilai standar deviasi yang ditunjukkan lebih kecil dari nilai rata-rata, sehingga penyebaran data yang terjadi merata. Variabel motivasi belajar menunjukkan nilai minimum sebesar 33, niali maksimum 56, nilai rata-rata 42,48, nilai standar deviasi 6,138. 
Nilai standar deviasi yang ditunjukkan lebih kecil dari nilai rata-rata, sehingga penyebaran data yang terjadi merata.

Table 4. Uji Validitas

\begin{tabular}{ccccc}
\hline Variabel & Pernyataan & $\begin{array}{c}\text { Pearson correlation } \\
(\mathbf{r} \text { hitung})\end{array}$ & (r tabel) & Keterangan \\
\hline & X1 & 0,679 & 0,2480 & Valid \\
\hline X2 & 0,735 & 0,2480 & Valid \\
\hline X3 & 0,788 & 0,2480 & Valid \\
\hline X4 & 0,666 & 0,2480 & Valid \\
\hline Pembelajaran Online(X) & 0,796 & 0,2480 & Valid \\
\hline & X6 & 0,614 & 0,2480 & Valid \\
\hline X7 & 0,617 & 0,2480 & Valid \\
\hline X8 & 0,303 & 0,2480 & Valid \\
\hline Y1 & 0,705 & 0,2480 & Valid \\
\hline Y2 & 0,747 & 0,2480 & Valid \\
\hline Y3 & 0,481 & 0,2480 & Valid \\
\hline Y4 & 0,822 & 0,2480 & Valid \\
\hline Y5 & 0,593 & 0,2480 & Valid \\
\hline Y6 & 0,338 & 0,2480 & Valid \\
\hline Y7 & 0,667 & 0,2480 & Valid \\
\hline Yotivasi Belajar (Y) & 0,368 & 0,2480 & Valid \\
\hline & Y9 & 0,652 & 0,2480 & Valid \\
\hline Y10 & 0,510 & 0,2480 & Valid \\
\hline Y11 & 0,596 & 0,2480 & Valid \\
\hline Y12 & 0,593 & 0,2480 & Valid \\
\hline & & &
\end{tabular}

Sumber: Software SPSS

Alat ukur yang digunakan peneliti dalam penelitian ini adalah instrumen berupa kuesioner. Kuesioner ini memiliki berbagai pernyataan yang berhubungan dengan variabel pembelajaran online dan motivasi belajar. Uji validitas dilakukan untuk mengetahui alat ukur yang digunakan dalam penelitian valid atau tidak valid. Validitas suatu alat ukur diperoleh dengan membandingkan nilai $r$ hitung dan $r$ tabel. Nilai $r$ hitung diperoleh dari uji validitas menggunakan SPSS, sementara $r$ tabel terdapat pada tabel $r$. Nilai $r$ tabel dihitung dengan cara $\mathrm{df}=61(63-2)$. Berdasarkan $\mathrm{r}$ tabel dengan $\mathrm{df}=61$ diperoleh nilai $\mathrm{r}$ tabel sebesar 0,2480 .

Hasil pada tabel di atas menunjukkan nilai $\mathrm{r}$ hitung dari setiap pernyataan $>\mathrm{r}$ tabel. Berdasarkan pertimbangan tersebut pernyataan-pernyataan yang ada diatas dikatakan valid, sehingga variabel pembelajaran online dan motivasi belajar adalah valid.

Table 5. Uji Reliabilitas

\begin{tabular}{lll}
\hline & Cronbach's alpha & Penilaian \\
\hline Pembelajaran Online & 0,791 & Reliabel \\
\hline Motivasi Belajar & 0,830 & Reliabel \\
\hline
\end{tabular}

Sumber: Software SPSS

Hasil dari uji reliabilitas digunakan untuk menilai apakah data yang diuji reliabel atau tidak. Data dikatakan reliabel jika nilai cronbach's alpha> 0,06 dan dikatakan tidak reliabel jika nilai cronbach's alpha< 0,06. Berdasarkan data diatas, nilai cronbach's alphapembelajaran online dan motivasi belajar lebih besar dari 0,06, yaitu 0,791>0,06 dan $0,830>0,06$. Berdasarkan perbandingan tersebut maka output dari pengujian data di atas adalah reliabel. 
Table 6. Uji Normalitas

\begin{tabular}{lcl}
\hline \multicolumn{1}{c}{ Variabel } & $\begin{array}{r}\text { Asymp. } \\
\text { Sig. (2-tailed) }\end{array}$ & Keterangan \\
\hline $\begin{array}{l}\text { Pembelajaran } \\
\text { Online }\end{array}$ & 0,200 & Normal \\
\hline
\end{tabular}

Sumber: Software SPSS

Uji normalitas dilakukan untuk menilai suatu data berupa nilai residual berdistribusi normal atau tidak. Data dikatakan berdistribusi normal jika nilai signifikansinya lebih besar dari 0,05. Tabel diatas menunjukkan nilai signifikansi 0,181 yang berarti lebih besar dari 0,05 sehingga data tersebutdikatakan berdistribusi normal.

Table 7. Uji Linearitas

\begin{tabular}{ccccccc}
\hline & & $\begin{array}{l}\text { Sum of } \\
\text { Squares }\end{array}$ & Df & $\begin{array}{l}\text { Mean } \\
\text { Square }\end{array}$ & F & Sig. \\
\hline $\begin{array}{c}\text { Motivasi } \\
\begin{array}{c}\text { Belajar*Pembelaj } \\
\text { aranOnline }\end{array}\end{array}$ & (Combined) & $1.169,036$ & 20 & 58,888 & 2,194 & 0,016 \\
\hline & Linearity & 578,886 & 1 & 471,098 & 17,552 & 0,000 \\
\hline & $\begin{array}{l}\text { Deviation } \\
\text { from } \\
\text { Linearity }\end{array}$ & 590,150 & 19 & 37,193 & 1,386 & 0,186 \\
\hline
\end{tabular}

\section{Sumber: Software SPSS}

Uji linearitas dilakukan dengan menguji kedua variabel yang bertujuan untuk menilai apakah kedua variabel tersebut memiliki hubungan yang linear atau tidak. Penilaian tersebut dilihat dari hasil uji linearitas. Jika nilai defiation from linearity lebih besar dari 0,05, maka kedua variabel tersebut memiliki hubungan yang linear dan sebaliknya. Data diatas menunjukkan nilai defiation from linearity sebesar 0,186, artinya lebih besar dari 0,05 sehingga variabel pembelajaran online dan motivasi belajar memiliki hubungan yang linear.

Table 8. Uji Regresi Linear Sederhana

\begin{tabular}{lclccc}
\hline Model & $\begin{array}{c}\text { Unstandardized } \\
\text { Coefficients }\end{array}$ & & $\begin{array}{c}\text { Standardizied } \\
\text { Coefficient Beta }\end{array}$ & t & I \\
\hline & $\mathrm{B}$ & $\begin{array}{l}\text { Standard } \\
\text { Error }\end{array}$ & & & \\
\hline (Constant) & 25,536 & 3,839 & & 6,653 & 0,000 \\
\hline $\begin{array}{l}\text { Pembelajaran } \\
\text { Online }\end{array}$ & 0,602 & 0,134 & 0,498 & 4,483 & 0,000 \\
\hline
\end{tabular}

Sumber: Software SPSS

Data diatas menunjukkan analisis regresi yang diperoleh dari aplikasi SPSS, sehingga persamaan yang dapat dibuat adalah sebagai berikut:

$$
\begin{aligned}
& Y=a+b X+e \\
& Y=25,536+0,602 X+e
\end{aligned}
$$

Dari persamaan diatas menunjukkan nilai konstanta sebesar 25,536 dan tidak ada error, yang berarti jika pembelajaran online dianggap sama dengan nol, maka motivasi belajar sebesar 25,536. Selain itu, nilai yang ditunjukkan pembelajaran online yaitu sebesar 0,602 
dan bernilai positif, artinya jika pembelajaran online bertambah 1, maka akan terjadi peningkatan terhadap motivasi belajar sebesar 0,602.

$H_{1}$ :Pembelajaran online berpengaruh positif terhadap motivasi belajar mahasiswa/mahasiswi Akuntansi.

Variabel pembelajaran online berpengaruh terhadap motivasi belajar jika nilai sinifikansinya lebih kecil dari 0,05 dan jika nilai signifikansinya lebih besar dari 0,05 maka variabel pembelajaran online tidak berpengaruh terhadap motivasi belajar. Tabel dibawah menunjukkan nilai signifikansi sebesar 0,000 dan bernilai positif, artinya nilai tersebut lebih kecil dari 0,05 , sehingga pembelajaran online berpengaruh positif terhadap motivasi belajar.

Table 9. Uji Hipotesis

\begin{tabular}{lcrlrl}
\hline Model & $\begin{array}{l}\text { Unstandardized } \\
\text { Coefficients }\end{array}$ & & $\begin{array}{l}\text { Standardizied } \\
\text { Coefficient } \\
\text { Beta }\end{array}$ & t & Sig. \\
\hline & $\mathrm{B}$ & $\begin{array}{l}\text { Standard } \\
\text { Error }\end{array}$ & & & \\
\hline (Constant) & 25,536 & 3,839 & & 6,653 & 0,000 \\
\hline $\begin{array}{l}\text { Pembelajaran } \\
\text { Online }\end{array}$ & 0,602 & 0,134 & 0,498 & 4,483 & 0,000 \\
\hline
\end{tabular}

Sumber: Software SPSS

Selain itu, kita juga dapat melihat seberapa besar pengaruh pembelajaran online terhadap motivasi belajar menggunakan koefisien determinan. Tabel dibawah menunjukkan nilai koefisien determinan ( $R$ Square) sebesar 0.248 atau 24,8\%. Nilai ini memiliki arti bahwa pembelajaran online berpengaruh terhadap motivasi belajar sebesar $24,8 \%$ dari $100 \%$ dan sisanya di pengaruhi oleh variabel lain yang tidak diukur dalam penelitian ini.

Table 10. Koefisien Determinan

\begin{tabular}{ccccc}
\hline Model & $\mathbf{R}$ & $\boldsymbol{R}$ Square & $\begin{array}{c}\text { Adjusted } \boldsymbol{R} \\
\text { Square }\end{array}$ & $\begin{array}{c}\text { Std. Error of the } \\
\text { Estimate }\end{array}$ \\
\hline $\mathbf{1}$ & 0,498 & 0,248 & 0,236 & 5.367 \\
\hline
\end{tabular}

Sumber: Software SPSS

Motivasi belajar merupakan dorongan dari dalam diri atau kemauan seseorang dalam belajar. Hal tersebut mencakup pertimbangan esensional bahwa motivasi belajar menuntut realisasi konkrit intrapersonal dalam proses pembelajaran. Motivasi belajar dipengaruhi oleh berbagai faktor, salah satunya media pembelajaran. Adanya media pembelajaran yang beragam menjadi faktor konkrit operasionaluntuk menciptakan materi pembelajaran yang lebih bervariasi, sehingga siswa lebih memahami dan nyaman dalam proses pembelajaran.

Hasil penelitian menunjukkan bahwa pembelajaran online berpengaruh positif terhadap motivasi belajar mahasiswa/mahasiswi akuntansi. Hal ini sesuai dengan penelitian yang dilakukan olehNirfayanti dan Nurbaeti (2019)bahwa penggunaan google classroom berpengaruh signifikan terhadap motivasi belajar. Brahma (2020)dengan menggunakan metode observasi dan wawancara dalam penelitiannya, menyatakan bahwa aplikasi zoom dapat membantu mahasiswa dalam proses pembelajaran di masa pandemic COVID 19. Media pembelajaran e-learning memiliki hubungan yang sangat tinggi terhadap motivasi belajar dalam proses pembelajaran (Aurora dan Effendi, 2019). 


\section{Simpulan dan Saran}

Dalam praktiknya, bidang pendidikan merupakan salah satu sektor operasional pembelajaran yang menjadimasalah di maisa pandemi COVID 19. Hal ini terjadi karena semua sekolah maupun universitas diharuskan melakukan pembelajaran secara online, sehingga motivasi belajar seseorang dibutuhkan dalam integrasinya dengan peningkatan mutu pendidikan. Penelitian ini dilakukan untuk meneliti pengaruh pembelajaran online terhadap motivasi belajar mahasiswa/mahasiswi FEB akuntansi UKSW di masa pandemi COVID 19. Variabel independen dalam penelitian ini yaitu pembelajaran online dan variabel dependen yaitu motivasi belajar. Hasil penelitian menunjukkan bahwa pembelajaran online berpengaruh positif terhadap motivasi belajar mahasiswa/mahasiswi FEB akuntansi UKSW. Adanya peningkatan terhadap motivasi belajar mahasiswa/mahasiswi terlebih di masa pandemi COVID 19 membuat pendidikan menjadi lebih baik.

COVID 19 merupakan virus berbahaya yang menimpa dunia. Virus tersebut terus meningkat sampai saat ini, sehingga sangat berpengaruh di berbagai bidang termasuk salah satunya pada bidang pendidikan. Motivasi belajar seseorang dalam proses pembelajaran menjadi penting dalam dunia pendidikan. Hal tersebut harus didukung dengan pemilihan metode pembelajaran yang tepat. Metode pembelajaran online banyak digunakan pengajar dan pendidik terlebih di masa pandemi COVID 19. Berdasarkan penelitian yang dilakukan penelitididapatkan hasil, pembelajaran online berpengaruh positif terhadap motivasi belajar mahasiswa/mahasiswi Akuntansi.Hal ini membuat mahasiswa/mahasiswi harus memahami sistem dan aplikasi yang digunakan dalam pembelajaran online dengan tujuan agar motivasi mahasiswa/mahasiswi tersebut meningkat.

Dalam proses penyelesaiannya, peneliti menemukan beberapa keterbatasan, di antaranya mengalami kesulitan dalam jaringan, karena penelitian ini dilakukan secara online dari daerah asal peneliti, Tidak bisa mengoordinasi responden secara langsung, Tidak bisa mengetahui kesulitan responden dalam proses pengisian butir-butir kuesioner dan Kurangnya variabel dalam penelitian ini.

Berdasarkan hasil penelitian dan keterbatasan yang ada, mempertimbangkan konklusi efektif yang diharapkan dapat terwujud dengan penelitian ini, maka peneliti menyarankan agar peneliti lain mencoba untuk menambahkan variabel selain pembelajaran online, penelitian mendatang diharapkan menggunakan metode penelitian yang lain (selain dengan kuesioner) untuk lebih menjaminefektivitas dari output penelitian yang diperoleh, dan memastikan memiliki jaringan internet yang baik pada saat proses penelitian.

\section{Daftar Pustaka}

Aghni, R. I. (2018). Fungsi dan Jenis Media Pembelajaran dalam Pembelajaran Akuntansi. Pendidikan Akuntansi Indonesia, XVI(1), 98-107. https://doi.org/https://doi.org/10.21831/jpai.v16i1.20173

Aurora, A., \& Effendi, H. (2019). Pengaruh Penggunaan Media Pembelajaran E-learning terhadap Motivasi Belajar Mahasiswa di Universitas Negeri Padang. 05(02), 11-16. https://doi.org/https://doi.org/10.24036/jtev.v5i2.105133

Brahma, I. A. (2020). Penggunaan Zoom sebagai Pembelajaran Berbasis Online dalam Mata Kuliah Sosiologi dan Antropologi pada Mahasiswa PPKN di STKIP Kusumanegara Jakarta. 97-102. https://doi.org/http://dx.doi.org/10.37905/aksara.6.2.97-102.2020 Abstrak

Danaswari, C., \& Gafur, A. (2018). Multimedia Pembelajaran Berbasis Web pada Mata iiPelajaran Akuntansi SMA untuk Peningkatan Motivasi dan Hasil Belajar. Inovasi Teknologi

Pendidikan,

5(2),

204-218. 
https://doi.org/https://doi.org/10.21831/jitp.v5i2.15543

Daryanto. (2016). Media Pembelajaran (2nd ed.). Yogyakarta: Penerbit Gava Media.

Dimas, C. (2020). Dampak Corona ke Dunia Pendidikan.

Hulu, V. T., \& Sinaga, T. R. (2019). Analisis Data Statistik Parametrik Aplikasi SPSS dan STATCAL: Sebuah Pengantar untuk Kesehatan (J. Simarmata, Ed.). Yayasan Kita Menulis.

Irmayanti, S., \& Nugroho, M. A. (2016). Pengembangan Media Pembelajaran Akuntansi Berbasis Web Blog untuk Meningkatkan Motivasi Belajar. Pendidikan Akuntansi Indonesia, XIV(1), 45-54. https://doi.org/https://doi.org/10.21831/jpai.v14i1.11366

Januar, P. G. (2015). Apa itu Belajar?

Kurniawan, A. (2019). Pengolahan Riset Ekonomi Jadi Mudah dengan IBM SPSS. Jakad Media Publishing.

Kusumadyahdewi. (2017). Pentingnya Motivasi dalam Pembelajaran Akuntansi sebagai Dasar Manajemen Keuangan Pribadi. PIPS, 3(2), 130-138. https://doi.org/10.18860/jpips.v3i2.6860

Marzuki, A., Armereo, C., \& Rahayu, P. F. (2020). Praktikum Statistik. Ahli Media Press.

Nirfayanti, \& Nurbaeti. (2019). Pengaruh Media Pembelajaran Google Classroom dalam Pembelajaran Analisis Real. Penelitian Matematika Dan Pendidikan Matematika, 2(1), 50-59.

Noor, K. B. N., \& Aisyah, M. N. (2018). Development of Interactive Learning Media Based on Computer to Improve Student Learning Motivation. Pendidikan Akuntansi Indonesia, XVI(2), 70-81. https://doi.org/https://doi.org/10.21831/jpai.v16i2.22054

Rista, K., \& Ariyanto, E. A. (2018). Pentingnya Pendidikan dan Meningkatkan Motivasi Belajar Anak. Abdikarya, 139-140. https://doi.org/https://doi.org/10.30996/abdikarya.v1i2.2076.g1767

Riyana, C. M. P. (2018). Konsep Pembelajaran Online.

Rusman. (2017). Belajar dan Pembelajaran (1st ed.). Jakarta: PT Kharisma Putra Utama.

Sardiman, A. M. (2016). Interaksi dan Motivasi Belajar Mengajar (1st, Cetakan ed.). Jakarta: PT Rajagrafindo Persada.

Sitorus, Y. I. (2020). Analisis Motivasi Belajar Siswa Menggunakan Video Animasi sebagai Alternatif Pembelajaran Jarak Jauh (PJJ) pada Materi Segitiga di SMP As'sadah Kelas VII A. (May).

Wahidmurni, D. (2017). Pemaparan Metode penelitian Kuantitatif. Ekp, 13(3), 1576-1580. 